the word 'invisible' contained in Shirley's comedy "The Bird in a Cage" (1633). The last possibility, towards which the author leans, is that it was a title devised by Theodore Haak to contain an implicit allusion to Comenius's plan of an international pansophic college for scientific research to be erected in London. This plan was much to the fore during Comenius's visit to England in 1641-42, and the scheme was set out in detail in his manuscript treatise, "Via Lucis" (1642). Haak was a German from the Palatinate who had been one of the principal supporters of the plan to establish a scientific academy in London. He regarded the informal scientific meetings as the nucleus of a future State college of science and is likely to have used the expression "Invisible College" in conversation with Boyle and others. The "Philosophical College" was thus the "Invisible College", until it definitely became the Royal Society.

\section{Medicine and Eugenics}

The Galton Lecture to the Eugenics Society, by Prof. John A. Ryle, on medicine and eugenics, is printed in the Eugenics Review, 30, No. 1. In a carefully considered address, it is pointed out that the eugenic movement needs the fuller support of the medical profession, and that this can only be given when medical men receive a fuller training in human genetics than is now the case. The family doctor is now rarely prepared, even if asked, to give advice connected with eugenic prognosis, although men and women are increasingly prepared to discuss such matters. Practising physicians should be able to keep pedigree records of their patients who show mental and physical defects. Medical education should be altered so as to lay greater stress on animal and human genetics in place of some of the routine zoology and the more specialized biochemistry and biophysies. The constitutional variations which abound should be the subject of closer genetic study. Several chairs of human genetics should be instituted, and associated with them should be research centres concerned with morbid inheritance in man. Wider contacts of the Eugenics Society with medical societies throughout the country would be helpful. The foundation of a National Council is advocated, embodying an alliance between medicine, eugenics and sociology and having appropriate contacts with the Ministries of Health, Agriculture and Labour. The preservation of health as a primary function, with the treatment of disease as a secondary function, should become the new ideal.

\section{Forestry in Nyasaland}

PERHAPs the most important information contained in the annual report of the Forestry Department for the Nyasaland Protectorate (for the year ending December 31, 1936. Govt. Printer, Zomba, Nyasaland, 1937) are the remarks on soil erosion and the investigation work now being undertaken in this, considered to be one of the greatest dangers facing Africa as a whole. Extensive areas were examined with particular regard to overcrowding and to cultivation on steep hill slopes in parts of the southern province. On the subject of forest policy it is stated that provision is to be made for the demarcation, protection, and management of selected forests and woodlands by native authorities, where the objects of conservation are comparatively local. These local Government forests will be supplementary to the State forests, but they will in no way supersede the village forests which are managed by the village headmen solely in the interests of village needs. There will thus be three types of demarcated forests in the future, each managed by its own authority. One of the chief dangers in many parts, owing to the improvident habits of the people, is erosion. Provided that each type of forest reservation may be made to serve as a protective agent against this evil, the steps now being taken appear to meet existing problems.

\section{Science and Horticulture}

VoL. 6 of Scientific Horticulture (260 pp., 1938, from the Editor, R. T. Pearl, S.E. Agric. Coll., Wye, Kent, 4s. net, 4s. $6 d$. post paid) the journal of the Horticultural Education Association, contains a very useful series of reviews upon the science and practice of horticulture. A suitable introduction is provided by Mr. F. A. Secrett, who writes upon the enterprise and skill requisite for successful market gardening, and the need for "evolving schemes to assist Nature". The article is the text of an evening address delivered at the University of Reading during the Association's revision course in horticulture in September 1937. Papers read at this course are published in the present volume; they minister chiefly to the needs of flower growers, with emphasis upon carnations, roses, pot plants and chrysanthemums, both early and late. There are further papers on genetics in relation to horticulture, the nature of inheritance of flower colour, and on photoperiodism. Papers contributed specially to the volume include a review of recent Dutch research upon the growth and flowering of tulips and daffodils by Miss O. N. Purvis, upon hormones (M. Thomas), boron deficiency (A. W. Greenhill), chromosomes and their importance in horticulture (F. W. Sansome) and the place of school gardening in elementary and secondary schools $(J$. Ewing). The production of virus-free seed potatoes is discussed by P. A. Murphy, and the modified leader tree by T. Swarbrick, whilst the formation and development of cherries is described by M. B. Crane.

\section{The Royal Technical College, Glasgow}

IN the building up of the world-wide reputation of the 'Scots engineer', the Royal Technical College, Glasgow, may fairly claim to have played a very large part, and much of this work has been done in its evening classes. It is noteworthy that of all the colleges that come within the purview of the University Grants Committee, the R.T.C. has far and away the largest number of evening students. Its recently published annual report shows that, notwithstanding the transfer of the classes in music, with about a hundred students, at the end of the preceding session, to the Scottish National Academy, there was an increase in the evening student enrol. ment from 2,624 to 2,665 , of whom a very large 
majority were engineering students. Some indication of the exceptional range and standard of the evening classes is given by the fact that the enrolment included 100 graduates of universities of Scotland, England, Ireland, Canada, India and China. An important, and seemingly long overdue event of the year was the formation of a Former Students' Association with a membership of seven hundred and correspondents in many parts of the world. The Association aims at "enabling former students to retain an interest in the affairs of the College" and as the honorary secretary is a member of the staff it may be hoped that it will help the College to retain an interest in the former students. An important source of strength for the College is the scheme of affiliation of continuation classes conducted by eight county education authorities and attended by more than seven thousand students. The Glasgow Careers Council (for Secondary Schools) co-operates with the Ministry of Labour in promoting visits of boys and girls with their teachers to various departments of the College.

\section{University Studies at Jerusalem}

A BULLETIN recently issued by the Hebrew University at Jerusalem discloses the fact that Polish students largely outnumber all others. The total enrolment last year was 779 , including 48 research students. Of the undergraduates, 433 were from Poland, 150 from Palestine, 49 from Germany, 35 from Lithuania and Latvia, 17 from Rumania and the rest from 18 other countries. The same bulletin contains an article by Dr. Dushkin, lecturer in educational method and administration, on the various activities of his department, including measures for improving and extending the teaching of Arabic. In the Palestinian schools, Arabic has been taught like Latin or Greek, with stress upon the analysis of grammatical forms and translation of classic texts. The University's policy is, on the contrary, to emphasize the conversational aspects of the language and to promote the employment of a minimum course for all Jewish children in colloquial Arabic, with simple reading and writing and instruction in Arabic folk.ways and customs. This is a diff. cult task owing to the prevalence of a snobbish contempt for the 'vulgar' spoken language of the common people, which differs widely from the classic Arabic of literature and is not taught by the Arabs in their own schools. The department is largely under the influence of American educational theory, the chair of the principles of education being held by Prof. Kaplan of New York, for many years a professor at the Jewish Theological Seminary there and principal of its Teachers' Institute, and a leader of the Society for the Advancement of Judaism and of the Reconstruction Movement in American Jewry.

\section{King Edward's Hospital Fund for London}

THE fortieth annual report of King Edward's Hospital Fund for London, recently issued and covering the year 1936, gives an account of the finances of the Fund and of the grants recommended. The ordinary distribution remained unchanged at
$£ 300,000$, to which was added a first contribution of $£ 2,000$ in respect of work done for hospital outpatients by district nursing associations. Grants were made to 146 hospitals and 56 convalescent homes. The contributions to the Fund included a capital gift of $£ 20,000$ from His late Majesty, King George V. The Fund has acquired an additional 7 grams of radium, thus bringing the amount under the Fund's control up to a total of 17 grams. An account is given of the work of the Propaganda Committee, which includes the production of a new film on hospital progress, specially suited to school audiences.

\section{Eradication of Bovine Tuberculosis}

THE Register of Attested Herds in Great Britain, under the Tuberculosis (Attested Herds) Schemes, which has been recently published, gives particulars of the herds on the Register on December 31. At that date there were 812 attested herds with 37,000 cattle in England and Wales, and 640 herds in Scot. land with 50,500 cattle, a considerable increase over the previous year. The Register gives the names and addresses of the owners and the breeds of cattle, and can be obtained on application to the Ministry of Agriculture and Fisheries, 7 Whitehall Place, London, S.W.1, or, for Scotland, 15 Moray Place, Edinburgh, 3. The issue of a certificate of attestation is evidence that the owner of the herd has taken steps to eradicate tuberculosis from the herd, and that as a result of an official tuberculin test, the herd has been found to be free from tuberculosis.

\section{Air-borne Traffic and Infectious Diseases}

The Minister of Health has made regulations, similar to the Port Sanitary Regulations, 1933, designed to prevent the introduction of infectious diseases into Great Britain through the medium of air-borne traffic which came into force on July 1. The authorities responsible for the administration of these "Aircraft Regulations" are the port health authorities for aerodromes at ports, and elsewhere the local authorities of the districts in which the aerodromes are situated. The regulations authorize, if necessary, temporary detention of aircraft, medical inspection of passengers and crews, cleansing, disinfection, etc. The issue of these regulations marks a further advance in the policy for the provision of health services suitable for modern conditions.

\section{The Vale of Neath}

THE National Museum of Wales has initiated a series of studies of the origin of Welsh scenery with a small pamphlet on the "River Scenery at the Head of the Vale of Neath", by Dr. F. J. North. The area covered is about sixty square miles and is one of great scenic charm. The studies do not necessarily embody original work, but they aim at giving popular descriptions of the origin of the land forms with as little use of technical terms as possible. Where technicalities are unavoidable they are fully explained. The present study is a good example of intelligent popularization both in its wording and its diagrams and illustrations. 